\title{
Uji Aktivitas Antibakteri Ekstrak Daun Suruhan (Peperomia pellucida L. Kunth) terhadap Klebsiella pneumoniae
}

\section{Antibacterial Activity of Suruhan Leaf Extract (Peperomia pellucida L. Kunth) against Klebsiella pneumoniae}

\author{
Destik Wulandari ${ }^{1^{*}}$ dan Isna Jati Asih ${ }^{2^{*}}$ \\ Farmasi, Fakultas Farmasi, Universitas Setia Budi \\ email:destikhakim@gmail.com
}

\begin{abstract}
ABSTRAK
Klebsiella pneumoniae merupakan salah patogen yang merupakan bakteri gram negative penyebab penyakit pneumonia. Pengobatan infeksi bakteri Klebsiella pneumoniae dilakukan melalui penggunaan antibiotik. Fenomena resistensi telah mendorong pencarian antimikroba berbasis natura dimana salah satu tanaman yang mempunyai potensi besar sebagai antibakteri adalah suruhan (Peperomia pellucida L. Kunth).

Tujuan dari penelitian ini adalah untuk mengetahui aktivitas antibakteri, nilai Konsentrasi Hambat Minimum (KHM) dan Konsentrasi Bunuh Minimum (KBM) dari ekstrak daun suruhan terhadap Klebsiella pneumoniae menggunakan metode dilusi cair. Metode ektraksi yang digunakan dalam penelitian ini adalah dengan maserasi. Ekstrak yang diperoleh kemudian diujikan dengan konsentrasi 100\%; 50\%; 25\%; 12,5\%; 6,25\%; 3,125\%; 1,562\%; $0,781 \% ; 0,391 \%$ dan $0,195 \%(v / v)$.

Hasil penelitian menunjukkan ekstrak daun suruhan mempunyai aktivitas antibakteri terhadap Klebsiella pneumoniae dengan nilai KBM sebesar 25\%.
\end{abstract}

Kata Kunci:Klebsiella pneumoniae, Peperomia pellucida L. Kunth, dilusi cair, KBM

\begin{abstract}
Klebsiella pneumoniae is one of the pathogens which are gram negative bacteria and that causes pneumonia. Treatment of Klebsiella pneumoniae bacterial infection is performed through the use of antibiotics. The phenomenon of resistance has encouraged the search for natura-based antimicrobials where one of the plants with antibacterial potency is suruhan (Peperomia pellucida L. Kunth).

The purpose of this study was to determine the antibacterial activity, the value of the Minimum Inhibitory Concentration (MIC) and the Minimum Killer Concentration (KBM) from the leaf extract of suruhan leaves on Klebsiella pneumoniae using a liquid dilution method. The extraction method used in this study was maceration. The extract obtained tested with a concentration of $100 \% ; 50 \% ; 25 \% ; 12.5 \% ; 6.25 \% ; 3.125 \% ; 1.562 \% ; 0.781 \% ; 0.391 \%$ and $0.195 \%$ (v / v).

The results showed that leaf extract had antibacterial activity against Klebsiella pneumoniae with a KBM value of $25 \%$.

Keywords:Klebsiella pneumoniae, Peperomia pellucida L. Kunth, broth dilution, MKC

\section{PENDAHULUAN}

Klebsiella pneumoniae adalah salah satu bakteri patogen menyebabkan infeksi pada manusia. Bakteri ini merupakan bakteri gram Gram negatif

yang menyebakan infeksi pada saluran kemih, pernafasan dan menyebakan terjadinya bakteremia pada individu yang mempunyai daya tahan tubuh lemah (Schroll, et al., 2010). Infeksi yang disebabkan oleh Klebsiella
\end{abstract}


pneumoniae adalah infeksi nosokomial (Adisasmito \& Hadinegoro, 2004). Klebsiella pneumoniaee ditemukan pada tubuh manusia di bagian saluran napas dan feses pada sekitar $5 \%$ orang normal (Jawetz et al.,1996).

Salah satu penyakit yang diakibatkan oleh adanya infeksi Klebsiella adalah pneumonia yang ditandai oleh demam tinggi, lesu dan disertai batuk kering. Batuk kering akan berlanjut menjadi batuk produktif yang disertai dengan sputum berdarah dan purulent (nanah). Penyakit ini berlanjut akan menyebabkan abses, nekrosis pada jaringan paru dan fibriosis paruparu. Angka kematian yang disebabkan oleh penyakit ini sekitar 40\%-60\% (Entjang 2003).

Upaya yang dilakukan untuk pengobatan yang disebabkan oleh infeksi Klebsiella pneumoniae adalah dengan antibiotik. Antibiotik yang biasa digunakan untuk menangani Klebsiella pneumoniaee adalah netilmisin, amikasin, seftriakson, dan amokxisilin asam klavulanat (Refdanita et al., 2004). Solusi yang digunakan untuk mengurangi penggunaan antibiotik salah satunya adalah dengan menggunakan bahan yang berasal dari alam.

Tanaman yang mempunyai potensi besar sebagai antibakteri adalah suruhan (Peperomia pellucida L. Kunth). Tumbuhan ini sangat mudah tumbuh diberbagai tempat terutama di daerah tropis yang lembab. Senyawa aktif yang terkandung dalam tanaman ini diantaranya adalah tanin dan flavonoid, dimana kedua senyawa ini dapat berperan sebagai antimikroba. Wei et al (2011) menyatakan bahwa tanaman suruhan mempunyai potensi sebagai antimikroba. Berdasarkan penelitian yang pernah dilakukan yang menyatakan bahwa daun suruhan mempunyai aktivitas antimikroba maka perlu dilakukan penelitian lainnya untuk menguji senyawa aktif pada daun suruhan dalam menghambat dan membunuh bakteri, salah satunya adalah Klebsiella pneumoniaee.

\section{METODE PENELITIAN}

\section{Bahan}

Bahan yang digunakan dalam penelitian ini dalah daun suruhan, bakteri Klebsiella pneumoniae, media Muller Hinton Agar (MHA), Brain Brain Heart Infusion (BHI), Nutrient agar (NA), etanol $70 \%$, quadest, DMSO, cat Gram A, Gram B, Gram C, dan Gram D.

\section{Alat}

Erlenmeyer, lampu spiritus, timbangan analitis, gelas Beker, gelas ukur, pipet volume, cawan Petri, tabung reaksi, inkas, jarum Ose, rak tabung reaksi, penangas air, ayakan nomer 60, oven, seperangkat alat rotary evaporator, pinset, gelas penyimpanan ekstrak, kertas saring, tabung ekstraksi, mikroskop, batang pengaduk, autoklaf Jalannya Penelitian

Tahap penelitian dimulai dari identifikasi daun suruhan. Identifikasi ini bertujuan untuk menghindari kesalahan bahan sampel yang akan digunakan untuk penelitian.Tanaman suruhan di determinasi di Laboratoriun Morfologi dan Sistematika Tumbuhan, fakultas Farmasi, Universitas Setia Budi Surakarta.

1. Pembuatan ekstrak daun suruhan 
Tumbuhan suruhan yang telah dideterminasi, diambil daunnya dan diekastraksi. Pembuatan ekstrak dilakukan dengan mengeringkan $10 \mathrm{~kg}$ daun suruhan yang telah dicuci bersih. Daun suruhan yang telah bersih kemudian dihaluskan dengan cara diblender hingga berbentuk serbuk yang biasa disebut dengan simplisia. Serbuk yang diperoleh kemudian diekstraksi dengan metode maserasi. Pelarut yang digunakan adalah etanol $70 \%$ dengan perbandingan antara serbuk dan pelarut adalah 1:5 selama lima hari terlindung cahaya. Selama proses maserasi sesekali diaduk. Endapan dipisahkan dengan cara disaring dan dipisahkan dari pelarutnya dengan vaccum evaporator hingga diperoleh ekstrak kental.

2. Pembuatan suspensi bakteri

Suspensi bakteri Klebsiella pneumoniaeyang digunakan dalam penelitian ini adalah bakteri dengan kepadatan $10^{6} \mathrm{CFU} / \mathrm{ml}$. Pembuatan suspensi bakteri distandarisasi dengan standar McFarland 0,5 yakni setara dengan kepadatan bakteri $10^{6} \mathrm{CFU} / \mathrm{ml}$ (Sutton, 2011). Pembuatan suspensi bakteri menggacu pada metode Assidqi dkk (2012). Bakteri diambil sebanyak 1 Ose dari media NA yang telah diinkubasi selama 24 jam, dimasukkan kedalam tabung yang berisi media $\mathrm{BHI}$. Suspensi bakteri disetarakan kekeruhannya dengan larutan standar McFarland 0,5.

3. Identifikasi Klebsiella pneumonia Identifikasi bakteri secara mikroskopis dilakukan dengan pewarnaan Gram dan kapsul. Pewarnaan Gram untuk membedakan bakteri dalam dua golongan berdasarkan sifat Gramnya yakni Gram positif atau negatif. Klebsiella pneumoniae termasuk bakteri Gram negatif yang ditandai dengan warna merah pada sel bakteri diakhir pewarnaan. Pewarnaan Gram dimulai dengan membuat preparat apusan pada objek glass dan dilakukan fiksasi. Selanjutnya apusan ditetesi dengan Gram A (kristal violet) kemudian ditetesi dengan Gram B (mordant) kemudian ditetesiGram C (pelarut), dan terakhir ditetesi dengan Gram D (safranin). Preparat kemudian diamati dibawah mikroskop perbesaran 100x

Pewarnaan kapsul dilakukan dengan menggunakan metode Burry Gins. Dua buah objek glass disiapkan, kemudian satu tetes tinta cina diletakkan disalah satu ujung objek glass dan dicampurkan dengan 1 tetes biakan Klebsiella pneumoniae. Apusan dibuat dengan menggunakan objek glass yang lain dan dibiarkan kering tanpa difiksasi. Preparat apusan kemudian ditetesi dengan kristal violet dan didiamkan selama 2 menit kemudian kelebihan cat dicuci dengan air mengalir. Selanjutnya preparat dikeringkan dan diamati dengan mikroskop pada perbesaran 100x.

4. Penentuan KHM dan KBM.

Uji aktivitas anti bakteri dengan metode dilusi dilakukan untuk menentukan nilai KHM dan KBM. Penelitian ini menggunakan 12 tabung reaksi yang terdiri dari 10 konsentarsi pengenceran yakni $100 \%$; 50\%; 25\%; $12,5 \% ; \quad 6,25 \% ; \quad 3,125 \% ; \quad 1,562 \%$; $0,781 \% ; 0,391 \% ; 0,195 \%$ dan kontrol negatif serta kontrol positif. Pengencer yang digunakan untuk membuat seri pengenceran adalah DMSO $2 \%$ 
KHM dari ekstrak daun
suruhan diperoleh dengan cara
menambahkan $0,5 \mathrm{ml}$ biakan cair Klebsiella pneumoniaee dengan kepadatan $10^{6} \mathrm{CFU} / \mathrm{ml}$ ke dalam masing-masing tabung reaksi yang berisi $1 \mathrm{ml}$ larutan uji dengan berbagai seri pengenceran. Tabung reaksi tersebut diinkubasi selama 24-48 jam pada suhu $37^{\circ} \mathrm{C}$. Pertumbuhan bakteri ditandai dengan terjadinya kekeruhan pada tabung reaksi yang berisi ekstrak etanol daun suruhan. Kekeruhan yang dihasilkan selanjutnya dibandingkan dengan kontrol.

Penentuan KBM dilakukan dengan metode streak plate. Kultur ulang ini dilakukan dengan menggoreskan larutan pada tabung reaksi yang tetap bening setelah dilakukan perlakuan (hasil KHM) pada media MHA. Kultur diinkubasi selama 24-48 jam dalam suhu $37^{\circ} \mathrm{C}$. KBM diperoleh dengan cara melihat ada tidaknya koloni bakteri yang tumbuh. Media MHA yang tidak ditumbuhi bakteri ditentukan sebagai KBM.

\section{HASIL DAN PEMBAHASAN}

1. Determinasi dan pembuatan ekstrak daun suruhan

Tanaman yang digunakan dalam penelitian ini adalah tanaman suruhan yang telah diidentifikasi di Laboratorium Morfologi dan Sistematika Tumbuhan, Fakultas Farmasi, Universitas Setia Budi Surakarta. Daun suruhan yang digunakan dalam penelitian ini adalah seberat $60 \mathrm{~kg}$, dikeringkan dan dibuat serbuk. Serbuk yang diperoleh adalah sebesar $650 \mathrm{gr}$. Serbuk kemudian diekstrak menggunakan pelarut etanol $70 \%$ dan jumlah ekstrak yang diperoleh adalah sebesar $114 \mathrm{gr}$ dengan rendemen sebesar $17,53 \%$.

2. Identifikasi Klebsiella pneumoniae Identifikasi dilakukan secara mikroskopis yakni dengan cara pewarnaan Gram dan pewarnaan kapsul, selain itu juga dilakukan identifikasi secara biokimia dengan ditanam di media KIA, SIM, LIA dan Citrat.

Hasil pewarnaan Gram pada Klebsiella pneumoniae menunjukkan warna sel adalah merah, sehingga disimpulkan bahwa Klebsiella pneumoniae bersifat Gram negatif. Bentuk sel dari bakteri ini adalah batang pendek dan tidak berkoloni. Metode pewarnaan kapsul yang digunakan adalah metode Burri-Gins. Hasil pewarnaannya adalah sel bakteri berwarna violet (ungu), latar belakang berwarna hitam dan kapsul akan berwarna transparan (Gambar 1A.). Kapsul pada bakteri tidak berwarna dikarenakan kapsulpada bakteri mudah ditembus oleh cat warna tetapi tidak dapat mengikat cat warna (Gambar 1B).

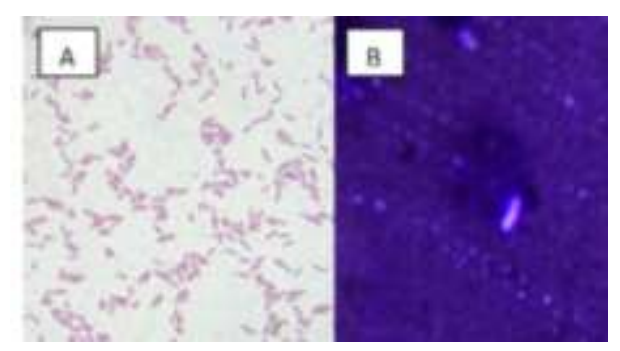

Gambar 1. Pewarnaan Gram, sel berwarna merah (A), pewarnaan kapsuldengan menggunakan metode Burri-Gins (B). 
Identifikasi lain yang digunakan untuk memastikan kebenaran Klebsiella pneumoniae adalah uji biokimia dengan ditanam pada media SIM, KIA, LIA dan Sitrat. Hasil uji biokimia dapat dilihat di Tabel 1 dan Gambar 2.

\section{Tabel 1. Hasil uji biokimia}

\begin{tabular}{ccc}
\hline Uji & Hasil & Pustaka \\
\hline SIM & --- & --- \\
KIA & ${\mathrm{A} / \mathrm{A} \mathrm{G}^{+} \mathrm{S}^{-}}^{-}$ & $\mathrm{A} / \mathrm{A} \mathrm{G}^{+} \mathrm{S}^{-}$ \\
LIA & $\mathrm{K} / \mathrm{K} \mathrm{S}^{\mathrm{K}}$ & $\mathrm{K} / \mathrm{K} \mathrm{S}^{-}$ \\
Citrat & + & + \\
\hline
\end{tabular}

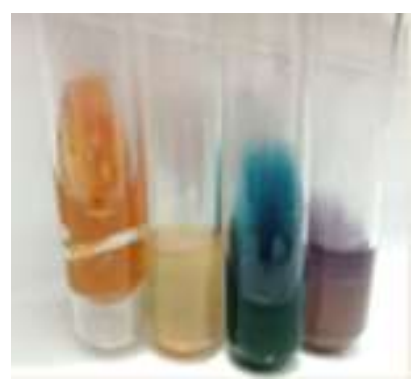

Gambar 2. Hasil uji biokimiadengan media KIA, SIM, Citrat dan LIA

3. Uji aktivitas antibakteri ekstrak daun suruhan terhadap Klebsiella pneumoniae dengan metode dilusi

Uji aktivitas anti bakteri ekstrak daun suruhan terhadap Klebsiella pneumoniae menggunakan metode dilusi. Tahap pertama dalam uji aktivitas anti bakteri ini dimulai dengan pembuatan suspensi dengan cara menanam bakteri pada media $\mathrm{BHI}$ kemudian diinkubasi pada suhu $37^{\circ} \mathrm{C}$ selama 24 jam kemudiansuspensibakteri disetarakan dengan McFarland 0,5 yang setara dengan $10^{6} \mathrm{CFU} / \mathrm{ml}$ bakteri.

Suspensi bakteri yang sudah dihitung kepadatannya kemudian digunakan untuk uji antibakteri dengan metode dilusi untuk nilai KHM) dan KBM) ekstrak daun suruhan terhadap Klebsiella pneumoniae. Nilai KHM tidak dapat diketahui karena warna ekstrak daun suruhan yang gelap yakni hijau tua sehingga kekeruhan yang diakibatkan oleh pertumbuhan bakteri tidak dapat dilihat (Gambar 3). Dzen (2003) salah satu cara yang dapat dilakukan untuk menentukan nilai KHM jika hasil ekstrak terlalu keruh adalah dengan cara difusi cakram atau metode $E$ test. Pertumbuhan bakteri terjadi pada kontrol positif yang berisi biakan bakteri, sedangkan pada kontrol negatif yang berisi ekstrak daun suruhan tidak terjadi pertumbuhan bakteri.

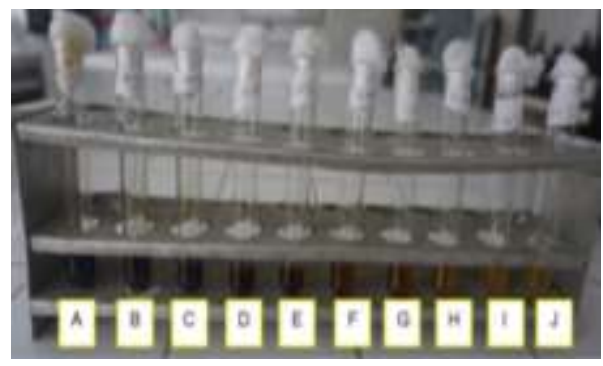

Gambar 3. Uji aktivitas antibakteri dengan metode dilusi

Keterangan:
A: ekstrak daun Suruhan 100\% + bakteri Klebsiella pneumoniae
B: ekstrak daun Suruhan 50\% + bakteri Klebsiella pneumoniae
C: ekstrak daun Suruhan 25\% + bakteri Klebsiella pneumoniae
D: ekstrak daun Suruhan 12,5\% + bakteri Klebsiella pneumoniae
E: ekstrak daun Suruhan 6,25\% + bakteri Klebsiella pneumoniae
F: ekstrak daun Suruhan 3,125\%+ bakteri Klebsiella pneumoniae
G: ekstrak daun Suruhan 1,562\% + bakteri Klebsiella pneumoniae


$\mathrm{H}: \quad$ ekstrak daun Suruhan 0,781\%, + bakteri Klebsiella pneumoniae

I: ekstrak daun Suruhan 0,391\% + bakteri Klebsiella pneumoniae

$\mathrm{J}$ ekstrak daun Suruhan 0,19\%, + bakteri Klebsiella pneumoniae

$\mathrm{K}(+)$ : Suspensi Bakteri

$\mathrm{K}(-)$ : Ekstrak daun suruhan 100\%

Penentuan nilai KBM dilakukan dengan cara menggoreskan campuran pada masing-masing tabung reaksi hasil uji aktivitas bakteri dengan teknik dilusi cair ke media MHA (Gambar 4).
Hasil positif ditandai dengan terjadinya pertumbuhan bakteri di media MHA. Hasil penggoresan dapat dilihat di Tabel 2

Data yang diperoleh dari hasil penggoresan setiap konsentrasi hasil uji aktivitas antibakteri metode dilusi cair pada media MHA menunjukkan pada replikasi 1 dan 2 nilai KBM ekstrak daun suruhan terhadap Klebsiella pneumoniaee adalah $25 \%$. Hal ini ditunjukkan dengan tidak ditumbuhinya bakteri $25 \%$ di kuadran pada konsentarsi $25 \%$.

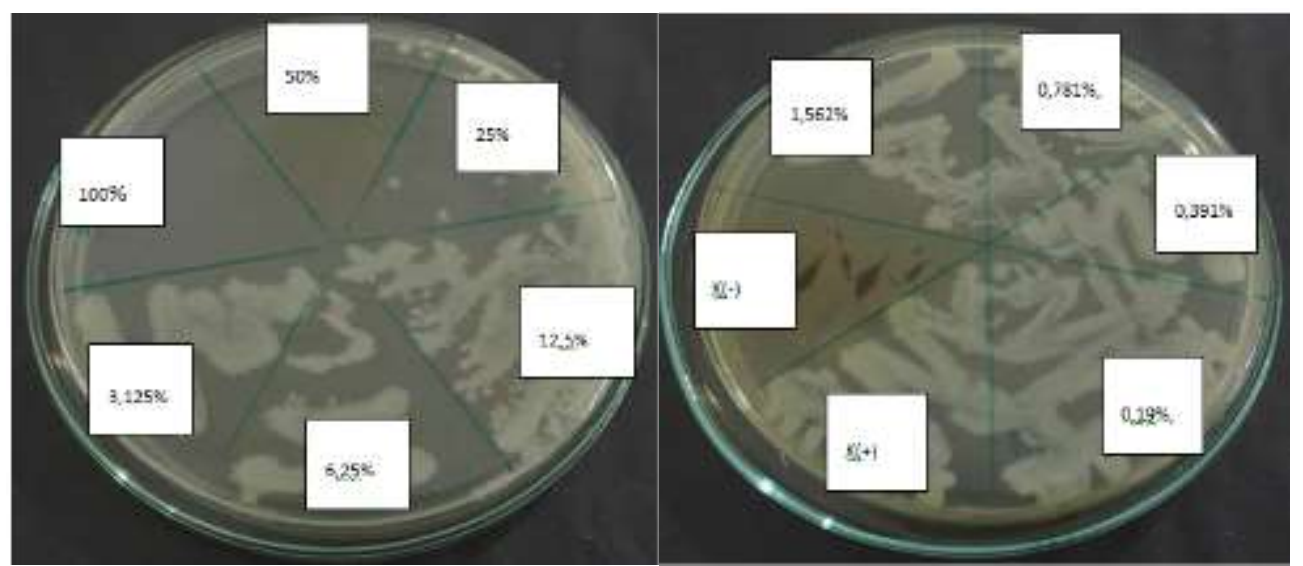

Gambar 4. Hasil uji penentuan nilai KBM dengan penggoresan pada media MHA

Tabel 2. Penentuan nilai KBM dengan penggoresan pada media MHA

\begin{tabular}{cccc} 
Konsentrasi & \multicolumn{3}{c}{ Replikasi } \\
$(\%)$ & 1 & 2 & 3 \\
50 & - & - & - \\
25 & - & - & + \\
12,5 & + & + & + \\
6,25 & + & + & + \\
3,125 & + & + & + \\
1,562 & + & + & + \\
0,781 & + & + & + \\
0,391 & + & + & + \\
0,19 & + & + & +
\end{tabular}

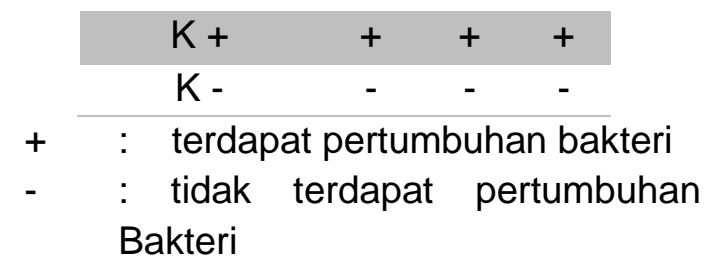

\section{KESIMPULAN}

1. Ekstrak daun Piperomia pellucida $L$. Kunt) mempunyai aktivitas antibakteri terhadap Klebsiella pneumoniae.

2. Secara in vitro nilai KHM, ekstrak daun suruhan terhadap Klebsiella pneumoniae tidak dapat ditentukan, 
sedangkan nilai KBM-nya adalah sebesar $25 \%$.

\section{DAFTAR PUSTAKA}

Adisasmito, A. W. \& Hadinegoro, S. R. S., 2004,Infeksi Bakteri Gram Negatif di ICU Anak:Epidemiologi, Manajemen Antibiotik dan Pencegahan, Sari Pediatri, 6 (1), 32-39.

Azrifitria, Aziz S, Chairul. 2010. Aktivitas antibakteri ekstrak etanolik daun dan umbi Crinum asiaticum L. terhadap bakteri penyebab jerawat. Majalah Farmasi Indonesia 21(4):256-241

Brooks GF, JS. Butel, SA Morse. 2005. Medical Microbiologi Kedokteran. Jakarta: Binarupa Aksara. HIm 3946

Cappucino, James G., LaboratoryManual, $6^{\mathrm{t}} \mathrm{h}$ Edition. Sinaeur Associates, Inc. Sunderland

Dalimartha, S.2006. Atlas Tumbuhan Obat Indonesia Jilid 4.Puspas

Dzen SM. 1994. Dasar-dasar Mikrobiologi. Laboratorium Mikrobiologi Fakultas Kedokteran Universitas Brawijaya Malang.

Edwars P.R and W. H. Ewing, 1972. Identification of Enterobactericeae .Third edition. Burgess Publishing Company.

Entjang, I., 2003, Mikrobiologi dan Parasitologi untuk Akademi Keperawatan. PT Citra Aditya Bakti: Bandung

Harbone JB, 1987. Metode Fitokimia: Penuntun Cara Modern Menganalisis Tumbuhan Terbitan kedua. Bandung: ITB Press.

Hariana, H.A. 2006. Tumbuhan Obat dan Khasiatnya, seri 3 Agrisehat. Penebar Swadaya, Jakarta

Jawetz, E, J. L., Adelberg, E. A., 1996, MikrobiologiKedokteran, Edisi XXII, Diterjemahkan oleh Bagian Mikrobiologi Fakultas
KedokteranUniversitas Airlangga, Salemba Medika.: Jakarta.

Miranti M, Prasetyorini dan Suwary C. 2013. Perbandingan aktivitas antibakteri ekstrak etanol $30 \%$ dan $96 \%$ kelopak bunga rosella (Hibiscus sabdariffal)terhadap bakteri Staphylococcus aureus. Ekologia 13 (1): 9-18

Pulak, M, Priya, A, Satya V. 2011. Ethno-medicinal, Phytochemical and Pharmacological review of an amazing medicinal herb Peperomia pellucida (L.) HBK, Research Journal of Pharmaceutical, Biological and Chemical. Vol 2(4), 358-364

Refdanita., Maksum, R., Nurgani, A., \& Endang, P., 2004, Pola Kepekaan Kuman Terhadap Antibiotika Di Ruang Rawat Intensif Rumah Sakit Fatmawati Jakarta Tahun 20012002. Repositori UI

Schroll, C., Barken, K. B., Krogfelt, K. A., \& Struve, C., 2010, Role Of Type 1 AndType 3 Fimbriae In Klebsiella pneumoniaeee Biofilm Formation, biomedcentral. 1471$2180 / 10 / 179$

Syarfati, Eriani dan Damhoeri. 2011. A the potential of Jarak China Jatropa multifida L) Secretion in healing new-wounded mice. Jurnal Natural $: 11$.

Tarigan, I.M. br, S. Bahri dan A. Saragih. 2012. Aktivitas Antihiperurisemia Ekstrak Etanol Herba Suruhan (Peperomia pellucida (L.) Kunth) Pada Mencit Jantan. Journal of Pharmaceutics and Pharmacology 1(1):37-43.

Wei, L.S., W. Wee, J.Y.F. Siong, \& D.F. Syamsumir. 2011. Characterization of Anticancer, Antimicrobial, Antioxidant Properties and Chemical Compositions of Peperomia pellucida Leaf Extract. Acta Medica Iranica 49(10): 670674 